\title{
Myf5 and MyoG gene SNPs associated with Bian chicken growth trait
}

\author{
Y. Wei ${ }^{1,2,3 *}$, G.X. Zhang ${ }^{1,2 *}$, T. Zhang ${ }^{1,2}$, J.Y. Wang ${ }^{1,2}$, Q.C. Fan ${ }^{1,2}$, Y. Tang ${ }^{1,2}$, \\ F.X. Ding ${ }^{4}$ and L. Zhang ${ }^{4}$ \\ ${ }^{1}$ Animal Science and Technology College, Yangzhou University, \\ Jiangsu Yangzhou, China \\ ${ }^{2}$ Key Laboratory for Animal Genetics, Breeding, \\ Reproduction and Molecular Design of Jiangsu Province, Jiangsu Yangzhou, China \\ ${ }^{3}$ Animal Husbandry and Veterinary Institute, \\ Jiangxi Academy of Agricultural Sciences, Jiangxi Nanchang, China \\ ${ }^{4}$ Animal Husbandry and Veterinary Institute, \\ Shanxi Academy of Agricultural Sciences, Shanxi Taiyuan, China \\ *These authors contributed equally to this study. \\ Corresponding author: J.Y. Wang \\ E-mail: jywang@yzu.edu.cn
}

Genet. Mol. Res. 15 (3): gmr.15037043

Received June 18, 2015

Accepted September 1, 2015

Published August 5, 2016

DOI http://dx.doi.org/10.4238/gmr.15037043

Copyright (C) 2016 The Authors. This is an open-access article distributed under the terms of the Creative Commons Attribution ShareAlike (CC BY-SA) 4.0 License

ABSTRACT. The growth trait is important in poultry production. We analyzed the association between single nucleotide polymorphisms (SNPs) in the Myf5 and MyoG gene and Bian chicken growth traits. SNPs in candidate genes of the Bian chickens were detected by the polymerase chain reaction-single strand conformation polymorphism method. Two mutation loci and six genotypes were identified in each candidate gene. In terms of growth traits, least square analysis showed that the $\mathrm{FF}$ genotype of the $M y o G$ was the advantage genotype and the IJ genotype of the $M y f 5$ was the disadvantage genotype for growth

Genetics and Molecular Research 15 (3): gmr.15037043 
trait in Bian chicken. Correlation analysis suggested that the different combination genotypes between $M y f 5$ and $M y o G$ genes had a significant effect on growth traits in Bian chickens. The result suggested that $M y o G$ and $M y f 5$ genes can be used in marker-assisted selection for improving the growth trait in Bian chicken.

Key words: Bian chickens; Myf5; MyoG; Growth trait; SNP; Conjoint analysis

\section{INTRODUCTION}

Body weight, a high heritability trait, is an important economic factor for broiler chickens and reflects the production level and economic benefits of a farm (Wang and Chen, 2004). Therefore, research into the genetic mechanism of growth traits is valuable. Using a candidate gene, quantitative trait loci that are related to growth traits are identified and isolated to provide theoretical basis for marker-assisted breeding (Bai et al., 2006).

The myogenic determination factor (MRF) family has four members: $M y f 5, M y o \mathrm{D}$, $M y o G$ and Myf6. The factors contain a basic helix-loop-helix domain that can dimerize with the E-protein to form protein dimmers (Murre et al., 1989; Sun and Baltimore, 1991; AnthonyCahill et al., 1992). They not only contribute to the differentiation and development of skeletal muscle precursor cells during the growth of embryo, but also related to skeletal muscle repair and hypertrophy (Lin and Konieczny, 1992; Perry and Rudnick, 2000). In chickens, the Myf5 gene is located on chromosome 1 and comprises three exons and two introns. It is $1215 \mathrm{bp}$ long. The $M y o G$ gene is located on chromosome 26 and also comprises three exons and two introns. It is $3402 \mathrm{bp}$ long. Gene knockout studies have clearly established the roles of the MRFs in myogenesis during mouse embryo development. Myf5 is expressed first during embryonic muscle development and initiates the conversion of muscle satellite cells to muscle stem cell with myoblast characteristics (Rescan, 2001). The $M y o G$ gene determines myoblast differentiation to myotubes (Neville et al., 1992; Naka et al., 2013). There appears to be a hierarchical and partially redundant relationship among the MRFs (Megeney and Rudnicki, 1995; Rudnicki and Jaenisch, 1995; Wang et al., 1996). Therefore, studying Myf5 and MyoG genes are of great significance for the improvement of meat production in livestock and poultry.

In this study, the Bian chicken breed, which is a national poultry genetic resource and is characterized by adaptability to poor quality feeds and environment, was chosen as the research object. To identify growth related molecular markers and provide a theoretical basis for breeding and conservation of Bian chickens at the molecular level, single nucleotide polymorphisms (SNPs) in the exons of the $M y f 5$ and $M y o G$ genes were detected by polymerase chain reaction single-strand conformation polymorphism (PCR-SSCP).

\section{MATERIAL AND METHODS}

\section{Chicken population}

Blood samples were collected from 360 female Bian chickens that had been randomly selected from the same feeding batch at Animal Husbandry and Veterinary Institute of Shanxi.

Genetics and Molecular Research 15 (3): gmr.15037043 
The body weight of each female Bian chicken was measured at $0,6,8,10,12,14,16,18$, and 20 weeks. Genomic DNA was extracted by the phenol-chloroform extraction method and dissolved in TE buffer (TE is derived from Tris and ethylene diamine tetraacetic acid). Before conducting the PCR, the concentration and purity of the DNA samples were measured by spectrophotometer.

\section{Primer design and PCR amplification}

Based on the chicken $M y f 5$ and $M y o G$ gene sequence (GenBank accession Nos. NW_003763474.1 and NC_006113.3), the primers were designed for amplifying all of the exon regions using the Primer Premier 5.0 software and were synthesized by the Sangon Biotech (Shanghai) Co., Ltd.

The PCR was performed in a $20-\mu \mathrm{L}$ mixture that contained $1 \mu \mathrm{L}$ chicken genomic DNA (50 ng/ $\mu \mathrm{L}), 2 \mu \mathrm{L} 10 \mathrm{X}$ buffer, $1.6 \mu \mathrm{L}$ deoxyribonucleotide triphosphates (dNTPs, $10 \mathrm{mM}), 1 \mu \mathrm{L}$ forward primer $(10 \mu \mathrm{M}), 1 \mu \mathrm{L}$ reverse primer $(10 \mu \mathrm{M}), 0.2 \mu \mathrm{L}$ Taq DNA polymerase, and 13.2 $\mu \mathrm{L}$ sterilized water. The amplification program was as follows: initial denaturation at $94^{\circ} \mathrm{C}$ for $5 \mathrm{~min}$, followed by 30 cycles of denaturation at $94^{\circ} \mathrm{C}$ for $30 \mathrm{~s}$, the annealing temperature for $30 \mathrm{~s}$ (see Table 1), extension at $72^{\circ} \mathrm{C}$ for $30 \mathrm{~s}$, and a final extension at $72^{\circ} \mathrm{C}$ for $10 \mathrm{~min}$. The PCR products were verified by $1 \%$ agarose gel electrophoresis.

Table 1. Primer sequences for polymerase chain reaction (PCR) amplification of the chicken $M y f 5$ and $M y o G$ genes.
\begin{tabular}{l|l|c|c|c}
\hline Primer & Sequence $\left(5^{\prime} \rightarrow 3^{\prime}\right)$ & Annealing temperature $\left({ }^{\circ} \mathrm{C}\right)$ & Fragment size (bp) & Location \\
\hline MY5 & $\begin{array}{l}\text { F: AGATGGAGGTGATGGACAGC } \\
\text { R: GGACGTGTTCTCTTCCTCA }\end{array}$ & 57.0 & 174 & Exon 3 \\
\hline MYG & $\begin{array}{l}\text { F: CTCCCCTCCTCTCTCAGAT } \\
\text { R: CTTTGCGCCAGCTCAGTT }\end{array}$ & 56.0 & 152 & Exon 3 \\
\hline
\end{tabular}

$\mathrm{F}=$ forward; $\mathrm{R}=$ reverse.

\section{SSCP and sequencing}

A mixture of the PCR production $(2 \mu \mathrm{L})$ and a denaturing buffer $(7 \mu \mathrm{L})$ was heated at $98^{\circ} \mathrm{C}$ for $10 \mathrm{~min}$ and then cooled on ice for $10 \mathrm{~min}$. The denatured PCR products were detected by $10 \%$ non-denaturing polyacrylamide gel electrophoresis at $220 \mathrm{~V}$ for $5 \mathrm{~min}$ and then 10 $\mathrm{V} / \mathrm{cm}$ for 10-12 h. After electrophoresis, the gels were developed by silver staining. Each genotype sample was sent for sequencing and alignment was conducted.

\section{Statistical analysis}

The general linear model was implemented using statistical software SPSS17.0 for multiple comparisons. The following linear model was used for least-squares analysis between growth traits and different genotypes in each gene

$$
\mathrm{Y}_{\mathrm{i}}=\mu+\mathrm{G}+\mathrm{e}_{\mathrm{i}}
$$

where $\mu$ was the overall mean, $\mathrm{G}$ was the effect of the $M y f 5$ or $M y o G$ gene, and $\mathrm{e}_{\mathrm{i}}$ was the random error. 
The following linear model was used for candidate genes conjoint analysis

$$
\mathrm{Y}_{\mathrm{ijk}}=\mu+\mathrm{G}_{\mathrm{i}}+\mathrm{G}_{\mathrm{j}}+\mathrm{G}_{\mathrm{ij}}+\mathrm{e}_{\mathrm{ijk}}
$$

(Equation 2)

where $\mu$ was the overall mean, $G_{i}$ was the effect of the $M y f 5$ gene, $G_{j}$ was the effect of the $M y o G$ gene, and $\mathrm{e}_{\mathrm{ij} \mathrm{k}}$, was the random error Unless otherwise stated, data are reported as means \pm standard error.

\section{RESULTS}

\section{Detection and sequencing results of PCR-SSCP}

The products amplified by primers MYG of the $M y o G$ gene and MY5 of the Myf5 gene showed polymorphisms. For primers MYG and MYf5, six genotypes were observed (Figure 1). Comparisons between the sequencing results and the original sequences of the candidate genes revealed nucleotide mutations. The mutations were T2927C and G2957A in exon 3 of MyoG (Figure 2), and C238T and G264A in exon 1 of Myf5 (Figure 3). Analysis using DNAman software showed that all mutation loci in the candidate genes were synonymous mutations.

\section{A}

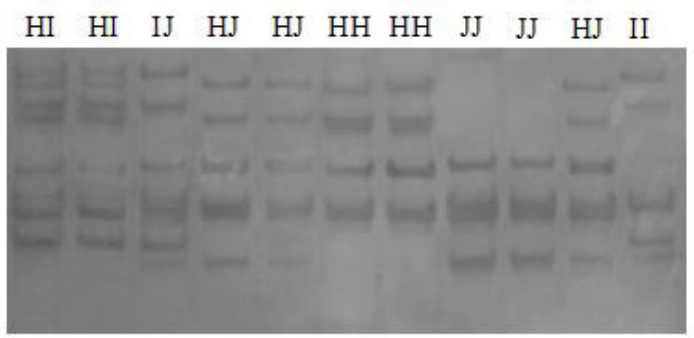

B

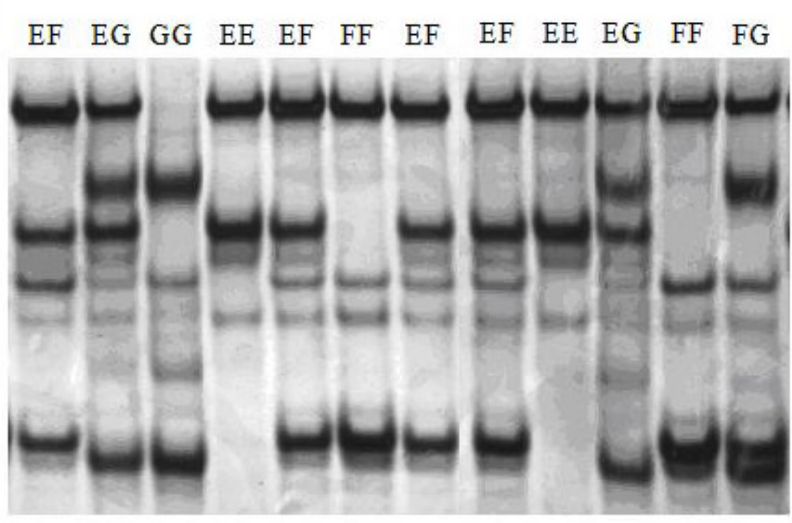

Figure 1. Polymerase chain reaction single-strand conformation polymorphism (PCR-SSCP) electrophoresis showing the different genotypes of the $M y o G(\mathbf{A})$ and $M y f 5$ (B) genes in Bian chickens. 

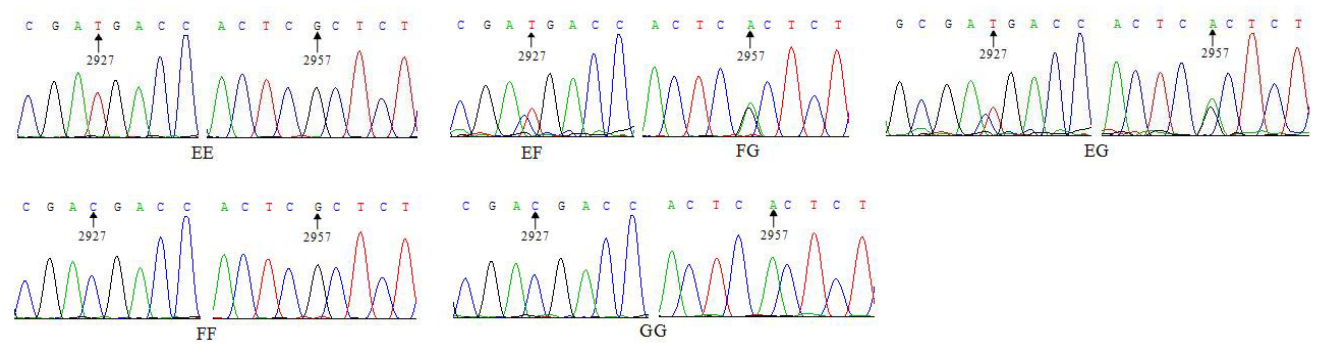

Figure 2. Sequence of different genotypes of primer MYG in Bian chickens.
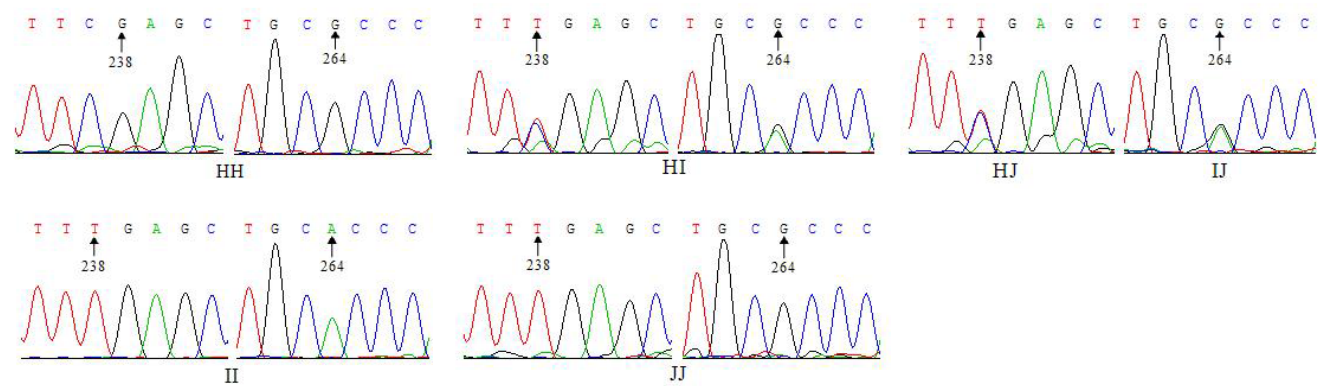

Figure 3. Sequence of different genotypes of primer MY5 in Bian chickens.

\section{Association between different genotypes of the MYG locus in the MyoG gene with growth traits}

The correlation analysis suggested that the MYG locus had a significant effect on growth traits from 0-20 weeks in Bian chickens (Table 2). Association analysis revealed that the FF genotype produced a significantly higher body weight at 0 week old compared with the EF genotype $(\mathrm{P}<0.05)$. Body weight in the FF genotype was also significantly higher than in the EE genotype at 6-10 weeks old $(\mathrm{P}<0.05)$. Furthermore, no significant association between the different genotypes and body weigh at the other time-points were detected $(\mathrm{P}>0.05)$.

Table 2. Associations between the genotypes and growth traits in the MYG loci of the $M y o G$ gene in Bian chickens.

\begin{tabular}{l|c|c|c|c|c|c}
\hline \multirow{2}{*}{ Body weight $(\mathrm{g})$} & \multicolumn{5}{|c}{ Genotypes } \\
\cline { 2 - 7 } & EE $(119)$ & FF $(32)$ & GG $(3)$ & EF $(119)$ & EG $(53)$ & FG $(34)$ \\
\hline 0 weeks & $36.57 \pm 0.30^{\mathrm{ab}}$ & $37.63 \pm 0.58^{\mathrm{a}}$ & $37.33 \pm 1.89^{\mathrm{ab}}$ & $36.38 \pm 0.30^{\mathrm{b}}$ & $36.98 \pm 0.45^{\mathrm{ab}}$ & $36.71 \pm 0.56^{\mathrm{ab}}$ \\
\hline 6 weeks & $439.81 \pm 4.13^{\mathrm{b}}$ & $460.56 \pm 7.98^{\mathrm{a}}$ & $428.33 \pm 26.05^{\mathrm{ab}}$ & $442.69 \pm 4.13^{\mathrm{ab}}$ & $444.45 \pm 6.20^{\mathrm{ab}}$ & $443.29 \pm 7.74^{\mathrm{ab}}$ \\
\hline 8 weeks & $617.82 \pm 6.05^{\mathrm{b}}$ & $643.75 \pm 11.66^{\mathrm{a}}$ & $601.67 \pm 38.07^{\mathrm{ab}}$ & $622.73 \pm 6.05^{\mathrm{ab}}$ & $625.45 \pm 9.06^{\mathrm{ab}}$ & $623.09 \pm 11.3^{\mathrm{ab}}$ \\
\hline 10 weeks & $785.50 \pm 7.29^{\mathrm{b}}$ & $818.41 \pm 14.06^{\mathrm{a}}$ & $762.67 \pm 45.90^{\mathrm{ab}}$ & $796.07 \pm 7.29^{\mathrm{ab}}$ & $795.93 \pm 10.92^{\mathrm{ab}}$ & $798.85 \pm 13.64^{\mathrm{ab}}$ \\
\hline 12 weeks & $977.43 \pm 9.17$ & $1009.75 \pm 17.68$ & $956.00 \pm 57.76$ & $992.03 \pm 9.17$ & $981.93 \pm 13.74$ & $984.85 \pm 17.16$ \\
\hline 14 weeks & $1122.10 \pm 10.96$ & $1161.00 \pm 21.12$ & $1090.67 \pm 69.00$ & $1145.49 \pm 10.96$ & $1120.68 \pm 16.42$ & $1125.88 \pm 20.49$ \\
\hline 16 weeks & $1171.74 \pm 13.60$ & $1201.78 \pm 26.22$ & $1140.67 \pm 85.64$ & $1205.61 \pm 13.60$ & $1167.36 \pm 20.38$ & $1189.35 \pm 25.44$ \\
\hline 18 weeks & $1301.70 \pm 14.97$ & $1353.06 \pm 28.88$ & $1282.67 \pm 94.30$ & $1334.61 \pm 14.97$ & $1294.19 \pm 22.44$ & $1306.35 \pm 28.01$ \\
\hline 20 weeks & $1427.97 \pm 17.25$ & $1490.19 \pm 33.27$ & $1422.33 \pm 108.66$ & $1466.33 \pm 17.25$ & $1431.74 \pm 25.85$ & $1441.65 \pm 32.28$ \\
\hline
\end{tabular}

In the same line, different small letters correspond to a statistically significant difference where $\mathrm{P}<0.05$.

Genetics and Molecular Research 15 (3): gmr.15037043 


\section{Association between different genotypes of the MY5 locus in the Myf5 gene with growth traits}

Correlation analysis suggested that the MY5 locus had a significant effect on growth traits at 0-20 weeks in Bian chickens (Table 3). Association analysis revealed that body weight in the II genotype was significantly higher than in the HJ genotype $(\mathrm{P}<0.01)$ and also significantly higher than $\mathrm{HH}$, JJ and $\mathrm{HI}$ genotypes $(\mathrm{P}<0.05)$ at 0 week old. Body weight in the IJ genotype was significantly lower than in the HH genotype $(\mathrm{P}<0.01)$ and also significantly lower than in the other genotypes $(\mathrm{P}<0.05)$ at 6 weeks old. Body weight in the IJ genotype was significantly lower than in the other genotypes except for the JJ genotype at 8 and 10 weeks old $(\mathrm{P}<0.05)$. Body weight in the IJ genotype was significantly lower than in the $\mathrm{HH}$ and $\mathrm{HI}$ genotypes and also lower than in the other genotypes at 12 weeks old $(\mathrm{P}<0.05)$. Body weight in the IJ genotype was lower than in the HH genotype at 14 weeks old $(\mathrm{P}<0.05)$. The HH genotype was extremely significantly higher than IJ genotype $(\mathrm{P}<0.01)$ and significantly higher than in the JJ genotypes at 16 to 20 weeks old $(\mathrm{P}<0.05)$. Furthermore, no significant associations between the different genotypes and body weigh at the other time-points were detected $(\mathrm{P}>0.05)$.

Table 3. Associations between the genotypes and growth traits in the MY5 loci of the Myf5 gene in Bian chickens.

\begin{tabular}{l|c|c|c|c|c|c}
\hline \multirow{2}{*}{ Body weight $(\mathrm{g})$} & \multicolumn{5}{|c}{ Genotypes } \\
\cline { 2 - 7 } & HH $(84)$ & II $(7)$ & JJ $(57)$ & HI $(51)$ & HJ $(136)$ & IJ $(25)$ \\
\hline 0 weeks & $36.54 \pm 0.36^{\mathrm{B}}$ & $39.85 \pm 1.23^{\mathrm{Aa}}$ & $36.36 \pm 0.43^{\mathrm{B}}$ & $36.17 \pm 0.46^{\mathrm{B}}$ & $36.76 \pm 0.28^{\mathrm{ABb}}$ & $37.56 \pm 0.65^{\mathrm{AB}}$ \\
\hline 6 weeks & $449.68 \pm 4.89^{\mathrm{A}}$ & $462.57 \pm 16.94^{\mathrm{ABa}}$ & $438.44 \pm 5.94^{\mathrm{ABa}}$ & $447.06 \pm 6.28^{\mathrm{ABa}}$ & $443.77 \pm 3.85^{\mathrm{ABa}}$ & $420.56 \pm 8.97^{\mathrm{Bb}}$ \\
\hline 8 weeks & $627.53 \pm 7.15^{\mathrm{a}}$ & $654.00 \pm 24.77^{\mathrm{a}}$ & $613.00 \pm 8.68^{\mathrm{ab}}$ & $630.61 \pm 9.18^{\mathrm{a}}$ & $625.56 \pm 5.62^{\mathrm{a}}$ & $595.80 \pm 13.11^{\mathrm{b}}$ \\
\hline 10 weeks & $802.48 \pm 8.61^{\mathrm{a}}$ & $837.00 \pm 29.85^{\mathrm{a}}$ & $784.36 \pm 10.46^{\mathrm{ab}}$ & $803.02 \pm 11.06^{\mathrm{a}}$ & $795.25 \pm 6.77^{\mathrm{a}}$ & $757.68 \pm 15.79^{\mathrm{b}}$ \\
\hline 12 weeks & $995.51 \pm 10.80^{\mathrm{A}}$ & $1038.57 \pm 37.43^{\mathrm{ABa}}$ & $981.36 \pm 13.12^{\mathrm{ABa}}$ & $996.94 \pm 13.87^{\mathrm{A}}$ & $985.86 \pm 8.49^{\mathrm{ABa}}$ & $932.84 \pm 19.81^{\mathrm{Bb}}$ \\
\hline 14 weeks & $1147.12 \pm 13.01^{\mathrm{a}}$ & $1172.28 \pm 45.08^{\mathrm{ab}}$ & $1122.17 \pm 15.80^{\mathrm{ab}}$ & $1136.98 \pm 16.70^{\mathrm{ab}}$ & $1134.50 \pm 10.22^{\mathrm{ab}}$ & $1085.44 \pm 23.85^{\mathrm{b}}$ \\
\hline 16 weeks & $1216.08 \pm 16.00^{\mathrm{Aa}}$ & $1199.71 \pm 55.44^{\mathrm{AB}}$ & $1156.45 \pm 19.43^{\mathrm{ABb}}$ & $1205.00 \pm 20.5^{\mathrm{AB}}$ & $1186.14 \pm 12.57^{\mathrm{AB}}$ & $1114.16 \pm 29.33^{\mathrm{Bb}}$ \\
\hline 18 weeks & $1347.38 \pm 17.69^{\mathrm{Aa}}$ & $1346.85 \pm 61.28^{\mathrm{AB}}$ & $1291.86 \pm 21.47^{\mathrm{ABb}}$ & $1334.61 \pm 14.97^{\mathrm{AB}}$ & $1294.19 \pm 22.44^{\mathrm{AB}}$ & $1306.35 \pm 28.01^{\mathrm{Bb}}$ \\
\hline 20 weeks & $1490.09 \pm 20.37^{\mathrm{Aa}}$ & $1442.47 \pm 16.02^{\mathrm{AB}}$ & $1427.72 \pm 24.73^{\mathrm{ABb}}$ & $1453.90 \pm 26.15^{\mathrm{AB}}$ & $1442.47 \pm 16.01^{\mathrm{AB}}$ & $1365.04 \pm 37.35^{\mathrm{Bb}}$ \\
\hline
\end{tabular}

In the same line, different capital letters correspond to a statistically significant difference where $\mathrm{P}<0.01$; different small letters correspond to a statistically significant difference where $\mathrm{P}<0.05$.

\section{Association between the different combination genotypes of the $M y o G$ and $M y f 5$ genes with growth traits}

Correlation analysis suggested that the different combination genotypes in the Myf5 and $M y o G$ genes had a significant effect on growth traits, especially in the later time- periods in Bian chickens (Table 4). Association analysis revealed that the combination genotypes had a significantly effect on body weight at 12 weeks $(\mathrm{P}<0.05)$ and a significantly effect at 16,18 and 20 weeks $(\mathrm{P}<0.01)$. There was not significant effect on weight at the other time-points.

Table 4. Associations between the different genotype combinations and growth traits of the candidate genes in
Bian chickens.
\begin{tabular}{l|c|c|c|c|c}
\hline Body weight & P value & Body weight & P value & Body weight & P value \\
\hline 0 weeks & 0.063 & 10 weeks & 0.072 & 16 weeks & 0.003 \\
\hline 6 weeks & 0.111 & 12 weeks & 0.029 & 18 weeks & 0.007 \\
\hline 8 weeks & 0.111 & 14 weeks & 0.088 & 20 weeks & 0.009 \\
\hline
\end{tabular}

Genetics and Molecular Research 15 (3): gmr.15037043 


\section{DISCUSSION}

The MRFs play key and different roles in the myogenic pathway. MyoD and Myf5 have overlapping functions in the differentiation and proliferation of muscle precursor cells such that deletion of one or the other does not significantly affect muscle development (Braun et al., 1992; Rudnicki et al., 1992), whereas deletion of both genes completely eliminates the skeletal muscle lineage (Rudnicki et al., 1993). MyoG and Myf6 function downstream of the myogenic pathway. The $M y o G$ factor controls myoblast differentiation to myotubes. In its absence, myoblasts are properly specified and positioned but there is a severe deficiency of muscle fibers (Hasty et al., 1993; Nabeshima et al., 1993). The Myf6 controls myotubes and the further integration of muscle fibers, but it is not essential for muscle development (Braun and Arnold, 1995; Patapoutian et al., 1995). The MRFs also have the ability to trigger skeletal muscle differentiation in non-muscle cells in vivo (Delfini and Duprez, 2004) and in vitro (Weintraub et al., 1991).

Using the PCR-SSCP technique, three mutations have been found in the $M y o G$ gene 5 ' regulatory region in seven chicken breeds. The result suggested that these variations might be associated with muscle fibers, thereby affecting the chicken growth (Wang et al., 2008). One study has shown that two polymorphic loci of the chicken $M y o G$ gene 5' regulatory region have a significant effect on muscle fiber density, muscle weight, leg muscle weight, and the rate of development of leg muscles (Wang et al., 2007). A study conducted by Ma (2010) showed that the different genotypes combinations of Myf5 gene in Gushi-Anka chickens had a significant effect on body weights at 8,10 and 12 weeks.

In this study, we found six genotypes in each of the candidate gene including $M y o G$ and $M y f 5$ gene. Association analysis revealed that the FF genotype of the $M y o G$ gene was the advantage genotype and the IJ genotype of $M y f 5$ gene was disadvantage genotype for growth trait in Bian chickens. As we know, a large number of SNPs exist in a genome. Although a single SNP can only provide limited information owing to its dimorphism, there is usually more than one SNP in a candidate gene. These SNPs can be used for association analysis between one or more candidate genes and traits (Cao et al., 2012). Correlation analysis suggested that the different combination genotypes in the $M y f 5$ and $M y o G$ genes had significant effects on growth traits from 16 to 20 weeks in Bian chickens. An interesting result of the body weight conferred by the advantage genotype combination in each gene did not necessarily occur at the same time-point (not listed in this article). However, we found that body weight conferred by the disadvantage genotype combination was the lowest in both candidate genes. The body weight in the EF/IJ combination was significantly lower than in the other associated genotypes from 6 to 20 weeks. Therefore, it is a possible to increase the average weight by reducing the number of EF/IJ combinations.

We plan to increase the number of experimental groups in order to verify the reliability of the EF/IJ combination used for the Bian chicken breeding. Meanwhile, we will continue to research the genotypes to discover the most that is advantageous combination for improving growth traits.

\section{CONCLUSIONS}

In this study, six SNPs were detected by PCR-SSCP in the exons of the candidate genes

Genetics and Molecular Research 15 (3): gmr.15037043 
in Bian chickens. Correlation analysis showed that reducing the number of EF/IJ combination could be used to improve the growth trait in Bian chickens. The findings in this study not only provide a basis for marker-assisted selection of Bian chickens, but also represent a reference for further studies in other chicken breeds.

\section{Conflicts of interest}

The authors declare no conflict of interest.

\section{ACKNOWLEDGMENTS}

Research supported by the Natural Science Foundation of Colleges and Universities in Jiang Su Province, China (\#12KJB230003), the Natural Science Foundation of China (\#31201793), the National Poultry Industry Technology System of China (\#nycytx-42-G1-05), the University Preponderant Discipline Construction Project of Jiang Su province, China, and the Animal Genetic Breeding and Molecular Design Key Laboratory of Jiang Su Province, China.

\section{REFERENCES}

Anthony-Cahill SJ, Benfield PA, Fairman R, Wasserman ZR, et al. (1992). Molecular characterization of helix-loop-helix peptides. Science 255: 979-983. http://dx.doi.org/10.1126/science.1312255

Bai JY, Zhang Q and Jia XP (2006). Comparison of different foreground and background selection methods in markerassisted introgression. Acta Genet. Sinica 33: 1073-1080. http://dx.doi.org/10.1016/S0379-4172(06)60144-3

Braun T and Arnold HH (1995). Inactivation of Myf-6 and Myf-5 genes in mice leads to alterations in skeletal muscle development. EMBO J. 14: 1176-1186.

Braun T, Rudnicki MA, Arnold HH and Jaenisch R (1992). Targeted inactivation of the muscle regulatory gene Myf5 results in abnormal rib development and perinatal death. Cell 71: 369-382. http://dx.doi.org/10.1016/0092$\underline{8674(92) 90507-9}$

Cao DG, Zhou Y, Lei QX, Han HX, et al. (2012). Association of polymorphisms of VLDLR gene with yolk traits in chicken. Acta Vet. Zootech. Sin. 43: 849-856.

Delfini MC and Duprez D (2004). Ectopic Myf5 or MyoD prevents the neuronal differentiation program in addition to inducing skeletal muscle differentiation, in the chick neural tube. Development 131: 713-723. http://dx.doi. org/10.1242/dev.00967

Hasty P, Bradley A, Morris JH, Edmondson DG, et al. (1993). Muscle deficiency and neonatal death in mice with a targeted mutation in the myogenin gene. Nature $364: 501-506$. http://dx.doi.org/10.1038/364501a0

Lin H and Konieczny SF (1992). Identification of MRF4, myogenin, and E12 oligomer complexes by chemical crosslinking and two-dimensional gel electrophoresis. J. Biol. Chem. 267: 4773-4780.

Ma XH (2010). Studies on polymorphism of Myf5 gene in Gushi-anka chickens $\mathrm{F}_{2}$ resource population. Master thesis. Henan Agriculture University.

Megeney LA and Rudnicki MA (1995). Determination versus differentiation and the MyoD family of transcription factors. Biochem. Cell Biol. 73: 723-732. http://dx.doi.org/10.1139/095-080

Murre C, McCaw PS and Baltimore D (1989). A new DNA binding and dimerization motif in immunoglobulin enhancer binding, daughterless, MyoD, and myc proteins. Cell 56: 777-783. http://dx.doi.org/10.1016/0092-8674(89)90682-X

Nabeshima Y, Hanaoka K, Hayasaka M, Esumi E, et al. (1993). Myogenin gene disruption results in perinatal lethality because of severe muscle defect. Nature 364: 532-535. http://dx.doi.org/10.1038/364532a 0

Naka A, Iida KT, Nakagawa Y, Iwasaki H, et al. (2013). TFE3 inhibits myoblast differentiation in C2C12 cells via down-regulating gene expression of myogenin. Biochem. Biophys. Res. Commun. 430: 664-669. http://dx.doi. org/10.1016/j.bbrc.2012.11.094

Neville CM, Schmidt M and Schmidt J (1992). Response of myogenic determination factors to cessation and resumption of electrical activity in skeletal muscle: a possible role for myogenin in denervation supersensitivity. Cell. Mol. Neurobiol. 12: 511-527. http://dx.doi.org/10.1007/BF00711232

Genetics and Molecular Research 15 (3): gmr.15037043 
Patapoutian A, Yoon JK, Miner JH, Wang S, et al. (1995). Disruption of the mouse MRF4 gene identifies multiple waves of myogenesis in the myotome. Development 121: 3347-3358.

Perry RL and Rudnick MA (2000). Molecular mechanisms regulating myogenic determination and differentiation. Front. Biosci. 5: D750-D767. http://dx.doi.org/10.2741/A548

Rescan PY (2001). Regulation and functions of myogenic regulatory factors in lower vertebrates. Comp. Biochem. Physiol. B Biochem. Mol. Biol. 130: 1-12. http://dx.doi.org/10.1016/S1096-4959(01)00412-2

Rudnicki MA and Jaenisch R (1995). The MyoD family of transcription factors and skeletal myogenesis. BioEssays 17: 203-209. http://dx.doi.org/10.1002/bies.950170306

Rudnicki MA, Braun T, Hinuma S and Jaenisch R (1992). Inactivation of MyoD in mice leads to up-regulation of the myogenic HLH gene Myf-5 and results in apparently normal muscle development. Cell 71: 383-390. http://dx.doi. org/10.1016/0092-8674(92)90508-A

Rudnicki MA, Schnegelsberg PN, Stead RH, Braun T, et al. (1993). MyoD or Myf-5 is required for the formation of skeletal muscle. Cell 75: 1351-1359. http://dx.doi.org/10.1016/0092-8674(93)90621-V

Sun XH and Baltimore D (1991). An inhibitory domain of E12 transcription factor prevents DNA binding in E12 homodimers but not in E12 heterodimers. Cell 64: 459-470. http://dx.doi.org/10.1016/0092-8674(91)90653-G

Wang JY and Chen GH (2004). Quantitative genetics and animal breeding. Nanjing

Wang Q, Liu YP, Jiang XS, Yang CW, et al. (2007). Correlation analysis of relationships between polymorphisms of high quality chicken myogenin gene and slaughter and meat quality traits. Yi Chuan 29: 1089-1098. http://dx.doi. org/10.1360/yc-007-1089

Wang QG, Li H, Li N, Wang YX, et al. (2008). Detection of single nucleotide polymorphism of Myogenin gene and population genetic analysis in chicken. J. Northeast Agric. Univ. 39: 82-25.

Wang Y, Schnegelsberg PN, Dausman J and Jaenisch R (1996). Functional redundancy of the muscle-specific transcription factors Myf5 and myogenin. Nature 379: 823-825. http://dx.doi.org/10.1038/379823a0

Weintraub H, Davis R, Tapscott S, Thayer M, et al. (1991). The myoD gene family: nodal point during specification of the muscle cell lineage. Science 251: 761-766. http://dx.doi.org/10.1126/science.1846704

Genetics and Molecular Research 15 (3): gmr.15037043 